\title{
The use of M-Health interventions for gestational diabetes mellitus: A descriptive literature review
}

\author{
Maryam Zahmatkeshan ${ }^{1}$, Azita Yazdani², Zahra Karbasi ${ }^{3}$, Mahboubeh Afifian $^{3}$, Maryam \\ Seraji $^{4}$, and Yousef Gholampour ${ }^{1}$ \\ ${ }^{1}$ Fasa University of Medical Science \\ ${ }^{2}$ Shiraz University of Medical Sciences \\ ${ }^{3}$ Tehran University of Medical Sciences \\ ${ }^{4}$ Zahedan University of Medical Sciences
}

May 20, 2020

\begin{abstract}
This study was attempted to review the evidence for or against the effectiveness of m-health interventions on health outcomes improvement and/or GDM management. Based on our findings, m-health interventions could enhance GDM patients' pregnancy outcomes. M-health can be one of the most prominent technologies for the management of GDM.
\end{abstract}

\author{
Abbreviations: \\ $\mathrm{GDM}=$ gestational diabetes mellitus \\ $\mathrm{SMS}=$ short message service \\ M-Health $=$ mobile health
}

\section{Introduction}

High-risk complications are estimated to occur in 10 percent of pregnancies and the evidence reveals the growing rate of high risk pregnancies(1). One of the most common complications that can occur during pregnancy is gestational diabetes mellitus (GDM) (2, 3), accounting for more than $80 \%$ of diabetes cases during pregnancy(2). GDM is found in $2 \%$ to $16 \%$ of all pregnancies(4), affecting about 150,000 pregnancies annually $(5,6)$. GDM affects both mother and child(7), and poses mother and child at risk of preeclampsia, cesarean delivery, congenital anomalies, fetal macrosomia, and the later development of type 2 diabetes(8). Given the increasing prevalence of GDM, new challenges are developed for health care professionals in antenatal care (9). High-risk pregnancies are often managed by hospitalizing patients for days and sometimes even weeks, leading to increase of financial burden (10) and stress for the patients (11). By proper monitoring, the risk and the disease costs will be reduced for a pregnant woman (12-14).

The recent advances in medical devices couple with development of intelligent sensors, Internet of Things (IoT), efficient telecommunication and information based smart decision support system (DSS), and mhealth technologies have unlocked the door of ample opportunities for patients' remote monitoring and health parameters tracking, thus enabling a paradigm shift in maternal health care $(13,15)$.

Recently, the dramatic advancements of information and communication technologies (ICTs) in health care has led to the development of m-health, creating substantial improvement in the provision of health services (16). M-health interventions have been developed along with technology advances (17). The widespread 
adoption of mobile phone technologies offers a promising opportunity to promote diabetes care and selfmanagement (18-20) through creating an active interaction between patients and healthcare professionals $(9,20)$.

The increasing storage capacity of mobile phones along with Wi-Fi accessibility represent the opportunity to offer mobile applications with the capabilities of tracking one or more health parameters such as glucose, diet, exercise and medication (19, 21-25). Mobile phone text messaging has enabled the provision of timely access to health advice, prompt self-monitoring, and individuals education about preventive health care services (26). Immediate delivery of short messages or direct calls to individuals is facilitated by mobile phone. Patients can be reminded over the cell phone at the time of the blood glucose measurement or other event (medication), leading to improvement of HbA1c levels and self-care regarding diet, medication, and exercise (20). Following emergent of m-health interventions in GDM, the development and evaluation of individual interventions have attracted more attention by the researchers. The previous systematic reviews either have focused on the effectiveness of m-health interventions $(4,16,27-34)$ or on a single condition (35-38). However, minimal evidence has been provided on the healthcare utilization or cost analyses.

Therefore, the present study was attempted to systematically review the effectiveness of GDM-related mhealth interventions from different perspectives. Recently, m-health has been introduced as a novel approach in GDM management. The delivery of face-to-face support has been examined in previous research; however, little is known about the implementation of $\mathrm{m}$-health as a possible alternative form of health service delivery for GDM patients. The aim of this descriptive literature review was to assess the evidence provided for or against the efficacy of m-health in GDM monitoring.

\section{Material and Methods}

\subsection{Search strategy}

Based on Preferred Reporting Items for Systematic Reviews and Meta-Analysis (PRISMA), we did our study (39). Databases of PubMed, Web of Science, Embase, and Scopus were searched from 2000 to July 10, 2018. The searches were not limited by language (studies in other languages were omitted due to incompatibility with the aim of this study).

The searches were done using the keywords of mobile health (m-health) and GDM. For the purpose of this review, m-health was defined as the use of technology to provide healthcare for patients with GDM using short message service (SMS), mobile application, and telemedicine system based on smartphones.

The stages for building the search query for the PubMed database are shown in table 1 . With respect to the instructions provided for each database, equivalent searches were then performed. Findings of each study were analyzed, relevant information was extracted, and finally obtained data were synthesized. The objectives and findings of each study are summarized in table 2.

\section{Table1. PubMed search query}

\subsection{Inclusion and exclusion criteria}

In this study, all articles evaluated the effectiveness of $\mathrm{m}$-health on GDM management by using m-health tools such as telemedicine system based on smartphones, m-Health, short message service (SMS), and mobile applications were included. Reviews and unpublished dissertations, commentaries, opinion papers, editorials, summaries were not considered. Studies that used telemedicine intervention without mobile phone, reported functions and implementation of the interventions unclearly, or presented descriptions of information technology were excluded.

\subsection{Selection of studies}

Selection of studies was done using four stages and based on PRISMA flow-diagram (39). In the first stage, identification, studies identified through database searching were collated in ENDNOTE software, 
and duplicates were omitted. In the second stage, two reviewers independently screened the titles and abstracts and removed irrelevant articles.

In the third stage, the full-text articles were independently evaluated for eligibility by the reviewers. In the fourth phase, the two reviewers (MZ and ZK) compared and verified their findings. Any disagreement was resolved either through discussion or involving a third reviewer (YGH). Information such as author, year, study design, m-health intervention, outcome, and results were retrieved.

\section{Results}

In Figure 1, the article selection process is demonstrated. Observing our defined inclusion and exclusion criteria, 27 studies were selected: 12 randomized controlled trials (RCTs); eight pilot studies; one crosssectional study; two non-randomized controlled trials; one case study; one prospective observational study; one qualitative study; and one development and test study.

\section{Figure 1. PRISMA Flow diagram of search strategy.}

The findings of the included studies with regard to efficacy of m-health interventions are summarized in Table 2 .

Among the 27 studies, $26 \%$ (7/27) used smartphone, without referring to its type, $14.9 \%(4 / 27)$ used the SMS, 33.3\% (9/27) used mobile-based applications, $18.5 \%$ (5/27) used telemedicine based on smartphones, and $7.1 \%(2 / 27)$ used SMS reminder system to investigate the efficacy of m-health interventions. Mostly, these studies supported the efficacy of m-health interventions $(n=4)(40-43)$.

Table2. Reviewed papers' characteristics and M-Health interventions and results from studies

\section{Discussion and Conclusions}

To manage disease and reduce the impact of chronic diseases, mobile health technologies can be useful through promotion of healthy behavior $(15,66,67)$. These newly introduced technologies can be served as self-monitoring tools for individual patients (68-70) and can effectively enhance women's health (71).

Literature review has supported the efficacy of mobile-health interventions in the management of diabetes, contributing patients, especially GDM patients (to control their blood sugar levels (20, 31, 72-80).

In the current investigation, all findings in this regard are presented using a structure composed of four main categories of m-health intervention. In the following these four branches are explained:

1. smartphone-based: Smartphones to support various aspects of care and patient-clinician interactions, provide high quality care and to support self-management of GDM $(46,47,54,57,58,62)$, The use of mhealth can increase GDM patients' compliance with lifestyle interventions and reduce future risk of T2DM and its sequelae (81); however, this result was not supported by McLean et al (41).

2. Smartphone-based telemedicine system: The impact of telemedicine interventions on GDM management have been investigated by a number of studies $(43,44,48,63,65)$. For instance, some studies have revealed the efficacy of telemedicine system in monitoring glucose, improving pregnancy outcomes in women with GDM, and enhancing quality of life of pregnant women with diabetes $(44,48,63,65)$. These findings are in line with the results of other studies $(4,82,83)$. Nevertheless, Homko et al (43) and Rasekaba et al (82) found no assciation between using a telemedicine system and pregnancy outcomes improvement.

4. SMS and reminders: Studies have demonstrated the potential and important role of SMS in altering the current paradigm of pregnancy care among women suffering from GDM $(49,52,61)$. Poorman has supported the usefulness of SMS for maternal and infant health, especially for women who cannot outreach traditional communication methods (33). Another study has revealed that Text4baby, a free mobile health information service delivering health-related SMS to pregnant and postpartum women, can enhance physical activity participation (84). Given that most of women suffering from GDM do not present for postpartum glucose testing despite recommendations, SMS can play an important role in increasing postpartum return 
rate ofwomen with GDM for diabetic screening test (56), However, Van Ryswyk has not confirmed this finding (40).

3. Mobile application: Nine out of 27 selected studies have evaluated the efficacy of mobile applications. Eight ones have provided evidence supporting the usefulness of mobile applications for managing GDM (9, $45,50,51,53,55,59,64)$. In contrast, Kennelly et al (42), in line with two other studies $(85,86)$ have reported lack of assoaciation between GDM management and using mobile applications.

Patient's satisfaction is one of the key issues in using mobile devices. We found that six studies $(46,47$, $49,51,57,61)$ have addressed the effect of m-health interventions on patient's satisfaction, revealing higher satisfaction level in pregnant women who received prenatal support via mobile phone. This finding is in line with findings of previous study $(87,88)$, Kim et al., also have demonstrated the association between high level of user satisfaction and using diabetes notepad application and the positive effect of this application on diabetes self-management (75).

Six studies have evaluated disease costs and reported that m-health intervention are economically cost effective benefit and can reduce disease costs $(49,51,54,58,61,64)$.

Considering the widespread use of mobile phones, various m-health tools have been developed for disease management and monitoring. However, the most effective tool for the management of GDM has not been reported yet. Therefore, in this systematic review, we have summarized the findings of previous studies on the effect of m-health interventions on GMD management.

The major limitation of this study is that only 4 databases were searched that could have led to missing of high-quality articles on m-health intervention for GDM. Published studies on GDM-related m-health interventions are increasing; however, the results are not consistent. Therefore, further evaluations are needed to obtain consistent conclusions regarding the usefulness of m-health interventions for GDM management. Future research are recommended to evaluate m-health interventions using multiple functions or stages, especially those popular outside clinical practice. we can conclude that m-health intervention is one of the most important technologies for GDM management.

Funding: None Declared

Key Message: Due to the risks of gestational diabetes and the growing incidence of this disease, by proper monitoring, the risk and the disease costs will be reduced for a pregnant woman. The widespread adoption of mobile phone technologies offers a promising opportunity to promote diabetes care and self-management by promote healthy behavior.

Conflicting interests: None Declared/ The Author(s) declare(s) that there is no conflict of interest.Ethical approval: Not ApplicableContributorship: MZ and YGH researched literature and conceived the study. MZ and YGH designed the study and conducted the search. MZ, AY, ZK, MA and MS selected articles for inclusion according to the inclusion/exclusion criteria. MZ wrote the first draft of the manuscript. All authors reviewed and edited the manuscript and approved the final version of the manuscript.

Acknowledgements: None

\section{References}

1. Penders J, Altini M, Van Hoof C, Dy E. Wearable sensors for healthier pregnancies. Proceedings of the IEEE. 2015;103(2):179-91.

2. Harrison TN, Sacks DA, Parry C, Macias M, Grant DSL, Lawrence JM. Acceptability of virtual prenatal visits for women with gestational diabetes. Women's Health Issues. 2017;27(3):351-5.

3. Mastrogiannis DS, Igwe E, Homko CJ. The role of telemedicine in the management of the pregnancy complicated by diabetes. Current Diabetes Reports. 2013;13(1):1-5. 
4. Rasekaba TM, Furler J, Blackberry I, Tacey M, Gray K, Lim K. Telemedicine interventions for gestational diabetes mellitus: A systematic review and meta-analysis. Diabetes Res Clin Pract. 2015;110(1):1-9.

5. Homko CJ, Deeb LC, Rohrbacher K, Mulla W, Mastrogiannis D, Gaughan J, et al. Impact of a telemedicine system with automated reminders on outcomes in women with gestational diabetes mellitus. Diabetes technology \& therapeutics. 2012;14(7):624-9.

6. Homko CJ, Santamore WP, Whiteman V, Bower M, Berger P, Geifman-Holtzman O, et al. Use of an internet-based telemedicine system to manage underserved women with gestational diabetes mellitus. Diabetes technology \& therapeutics. 2007;9(3):297-306.

7. Caballero-Ruiz E, Garcia-Saez G, Rigla M, Villaplana M, Pons B, Hernando ME. A web-based clinical decision support system for gestational diabetes: Automatic diet prescription and detection of insulin needs. Journal of perinatal medicine. 2017;102:35-49.

8. Yogev Y, Ben-Haroush A, Chen R, Kaplan B, Phillip M, Hod M. Continuous glucose monitoring for treatment adjustment in diabetic pregnancies - a pilot study. Diabetic medicine. 2003;20(7):558-62.

9. Garnweidner-Holme L, Andersen TH, Sando MW, Noll J, Lukasse M. Health Care Professionals' Attitudes Toward, and Experiences of Using, a Culture-Sensitive Smartphone App for Women with Gestational Diabetes Mellitus: Qualitative Study. Jmir Mhealth and Uhealth. 2018;6(5).

10. Vermeulen-Giovagnoli B, Peters C, Mischi M, van Pul C, Cottaar E, Oei S, editors. The development of an obstetric tele-monitoring system. Engineering in Medicine and Biology Society (EMBC), 2015 37th Annual International Conference of the IEEE; 2015: IEEE.

11. Jezewski J, Pawlak A, Horoba K, Wrobel J, Czabanski R, Jezewski M. Selected design issues of the medical cyber-physical system for telemonitoring pregnancy at home. Microprocessors and Microsystems. 2016;46:35-43.

12. Chen W, Hu J, Bouwstra S, Oetomo SB, Feijs L. Sensor integration for perinatology research. International Journal of Sensor Networks. 2010;9(1):38-49.

13. Kashem MA, Seddiqui M, Moalla N, Sekhari A, Ouzrout Y. Review on Telemonitoring of Maternal Health care Targeting Medical Cyber-Physical Systems. arXiv preprint arXiv:160707712. 2016.

14. Santhi V, Ramya K, Tarana A, Vinitha G. IOT based wearable health monitoring system for pregnant ladies using cc3200. International Journal of Advanced Research Methodology in Engineering \& Technology, ISSN. 2017;2456:6446.

15. Free C, Phillips G, Galli L, Watson L, Felix L, Edwards P, et al. The effectiveness of mobile-health technology-based health behaviour change or disease management interventions for health care consumers: a systematic review. PLoS medicine. 2013;10(1):e1001362.

16. Chen H, Chai Y, Dong L, Niu W, Zhang P. Effectiveness and appropriateness of mhealth interventions for maternal and child health: Systematic review. Journal of Medical Internet Research. 2018;20(1).

17. O'Brien CM, Cramp C, Dodd JM. Delivery of Dietary and Lifestyle Interventions in Pregnancy: Is it Time to Promote the Use of Electronic and Mobile Health Technologies? Seminars in Reproductive Medicine. 2016;34(2):e22-e7.

18. Garabedian LF, Ross-Degnan D, Wharam JF. Mobile Phone and Smartphone Technologies for Diabetes Care and Self-Management. Current Diabetes Reports. 2015;15(12).

19. El-Gayar O, Timsina P, Nawar N, Eid W. Mobile applications for diabetes self-management: status and potential. Journal of diabetes science and technology. 2013;7(1):247-62.

20. Liang X, Wang Q, Yang X, Cao J, Chen J, Mo X, et al. Effect of mobile phone intervention for diabetes on glycaemic control: a meta-analysis. Diabetic medicine. 2011;28(4):455-63. 
21. Chomutare T, Fernandez-Luque L, Årsand E, Hartvigsen G. Features of mobile diabetes applications: review of the literature and analysis of current applications compared against evidence-based guidelines. Journal of medical Internet research. 2011;13(3).

22. Årsand E, Tatara N, Østengen G, Hartvigsen G. Mobile phone-based self-management tools for type 2 diabetes: the few touch application. Journal of diabetes science and technology. 2010;4(2):328-36.

23. Istepanian RS, Zitouni K, Harry D, Moutosammy N, Sungoor A, Tang B, et al. Evaluation of a mobile phone telemonitoring system for glycaemic control in patients with diabetes. 2009.

24. Faridi Z, Liberti L, Shuval K, Northrup V, Ali A, Katz DL. Evaluating the impact of mobile telephone technology on type 2 diabetic patients' self-management: the NICHE pilot study. Journal of evaluation in clinical practice. 2008;14(3):465-9.

25. Carroll AE, Marrero DG, Downs SM. The HealthPia GlucoPack Diabetes phone: a usability study. Diabetes technology \& therapeutics. 2007;9(2):158-64.

26. Demiris G, Afrin LB, Speedie S, Courtney KL, Sondhi M, Vimarlund V, et al. Patient-centered applications: use of information technology to promote disease management and wellness. A white paper by the AMIA knowledge in motion working group. Journal of the American Medical Informatics Association. $2008 ; 15(1): 8-13$.

27. Al Dahdah M, Du Lou AD, Meadel C. Mobile health and maternal care: A winning combination for healthcare in the developing world? Health Policy and Technology. 2015;4(3):225-31.

28. Daly LM, Horey D, Middleton PF, Boyle FM, Flenady V. The Effect of Mobile App Interventions on Influencing Healthy Maternal Behavior and Improving Perinatal Health Outcomes: Systematic Review. JMIR mHealth and uHealth. 2018;6(8).

29. Feroz A, Perveen S, Aftab W. Role of mHealth applications for improving antenatal and postnatal care in low and middle income countries: a systematic review. BMC health services research. 2017;17(1):704.

30. Lee SH, Nurmatov UB, Nwaru BI, Mukherjee M, Grant L, Pagliari C. Effectiveness of mHealth interventions for maternal, newborn and child health in low-and middle-income countries: Systematic review and meta-analysis. Journal of global health. 2016;6(1).

31. Ming WK. Telemedicine Technologies for Diabetes in Pregnancy: A Systematic Review and MetaAnalysis. JMIR research protocols. 2016;18(11):e290.

32. Overdijkink SB, Velu AV, Rosman AN, Van Beukering MDM, Kok M, Steegers-Theunissen RPM. The usability and effectiveness of mobile health technology-based lifestyle and medical intervention apps supporting health care during pregnancy: Systematic review. Journal of Medical Internet Research. 2018;20(4).

33. Poorman E, Gazmararian J, Parker RM, Yang B, Elon L. Use of Text Messaging for Maternal and Infant Health: A Systematic Review of the Literature. Maternal and Child Health Journal. 2015;19(5):969-89.

34. Sondaal SFV, Browne JL, Amoakoh-Coleman M, Borgstein A, Miltenburg AS, Verwijs M, et al. Assessing the effect of mHealth interventions in improving maternal and neonatal care in low-and middle-income countries: a systematic review. PloS one. 2016;11(5):e0154664.

35. Archangeli C, Marti FA, Wobga-Pasiah EA, Zima B. Mobile health interventions for psychiatric conditions in children: a scoping review. Child and Adolescent Psychiatric Clinics. 2017;26(1):13-31.

36. Kovacs F, Torok M, Horvath C, Balogh AT, Zsedrovits T, Nagy A, et al. A new, phonocardiographybased telemetric fetal home monitoring system. Telemedicine and e-Health. 2010;16(8):878-82.

37. Meng Q, Song L, Wang X, Fan S, Che L, Zhang G, et al. Development of Health Intelligent Management Cloud Platform on Maternal and Infant Monitor. Zhongguo yi liao qi xie za zhi= Chinese journal of medical instrumentation. 2017;41(1):20-2. 
38. Noordam AC, Kuepper BM, Stekelenburg J, Milen A. Improvement of maternal health services through the use of mobile phones. Tropical Medicine \& International Health. 2011;16(5):622-6.

39. Moher D, Liberati A, Tetzlaff J, Altman DG. Preferred reporting items for systematic reviews and meta-analyses: the PRISMA statement. Annals of internal medicine. 2009;151(4):264-9.

40. Van Ryswyk EM, Middleton PF, Hague WM, Crowther CA. Postpartum sms reminders to women who have experienced gestational diabetes mellitus to test for type 2 diabetes: The diamind randomised controlled trial. Journal of Paediatrics and Child Health. 2015;51:37.

41. McLean A, Osgood N, Newstead-Angel J, Stanley K, Knowles D, Van Der Kamp W, et al. Building research capacity: Results of a feasibility study using a novel mHealth epidemiological data collection system within a gestational diabetes population. Studies in health technology and informatics2017. p. 228-32.

42. Kennelly MA, Ainscough K, Lindsay KL, O'Sullivan E, Gibney ER, McCarthy M, et al. Pregnancy Exercise and Nutrition With Smartphone Application Support: A Randomized Controlled Trial. Obstetrics and gynecology. 2018;131(5):818-26.

43. Homko CJ, Deeb LC, Rohrbacher K, Mulla W, Mastrogiannis D, Gaughan J, et al. Impact of a telemedicine system with automated reminders on outcomes in women with gestational diabetes mellitus. Diabetes Technol Ther. 2012;14(7):624-9.

44. Yang P, Lo W, He ZL, Xiao XM. Medical nutrition treatment of women with gestational diabetes mellitus by a telemedicine system based on smartphones. Journal of Obstetrics and Gynaecology Research. 2018;44(7):1228-34.

45. Skar JB, Garnweidner-Holme LM, Lukasse M, Terragni L. Women's experiences with using a smartphone app (the Pregnant plus app) to manage gestational diabetes mellitus in a randomised controlled trial. Midwifery. 2018;58:102-8.

46. Miremberg H, Ben-Ari T, Betzer T, Raphaeli H, Gasnier R, Barda G, et al. The impact of a daily smartphone-based feedback system among women with gestational diabetes on compliance, glycemic control, satisfaction, and pregnancy outcome: a randomized controlled trial. American Journal of Obstetrics and Gynecology. 2018;218(4).

47. Mackillop L, Hirst JE, Bartlett KJ, Birks JS, Clifton L, Farmer AJ, et al. Comparing the Efficacy of a Mobile Phone-Based Blood Glucose Management System With Standard Clinic Care in Women With Gestational Diabetes: Randomized Controlled Trial. Journal of Medical Internet Research. 2018;20(3).

48. Rigla M, Martinez-Sarriegui I, Garcia-Saez G, Pons B, Hernando ME. Gestational diabetes management using smart mobile telemedicine. Journal of diabetes science and technology. 2018;12(2):260-4.

49. Johnson QB, Berry DC. Impacting diabetes self-management in women with gestational diabetes mellitus using short messaging reminders. JMIR mHealth and uHealth. 2018;30(6):320-6.

50. Peleg M, Shahar Y, Quaglini S, Fux A, Garcia-Saez G, Goldstein A, et al. MobiGuide: a personalized and patient-centric decision-support system and its evaluation in the atrial fibrillation and gestational diabetes domains. User Modeling and User-Adapted Interaction. 2017;27(2):159-213.

51. Peleg M, Shahar Y, Quaglini S, Broens T, Budasu R, Fung N, et al. Assessment of a personalized and distributed patient guidance system. International Journal of Medical Informatics. 2017;101:108-30.

52. Nicholson WK, Beckham AJ, Hatley K, Diamond M, Johnson LS, Green SL, et al. The Gestational Diabetes Management System (GooDMomS): development, feasibility and lessons learned from a patientinformed, web-based pregnancy and postpartum lifestyle intervention. Bmc Pregnancy and Childbirth. $2016 ; 16$.

53. Marko KI, Krapf JM, Meltzer AC, Oh J, Ganju N, Martinez AG, et al. Testing the Feasibility of Remote Patient Monitoring in Prenatal Care Using a Mobile App and Connected Devices: A Prospective 
Observational Trial. Jmir Research Protocols. 2016;5(4).

54. Wickramasinghe N, Teoh SY, Mercieca P. Using Smartphones for Accountable Care and Evidence-based Decision Making in Managing Gestational Diabetes: An Australian Case Study. Communications of the Association for Information Systems. 2015;37:705-16.

55. Jo S, Park HA. Development and Evaluation of a Smartphone Application for Managing Gestational Diabetes Mellitus. Healthcare Informatics Research. 2016;22(1):11-21.

56. Mohd Suan MA. Return for Postpartum Oral Glucose Tolerance Test Following Gestational Diabetes Mellitus. Asia-Pacific journal of public health. 2015;27(6):601-9.

57. Hirst JE, Mackillop L, Loerup L, Kevat DA, Bartlett K, Gibson O, et al. Acceptability and user satisfaction of a smartphone-based, interactive blood glucose management system in women with gestational diabetes mellitus. Journal of diabetes science and technology. 2015;9(1):111-5.

58. Teoh SY, Mercieca P, Wickramasinghe N, editors. The use of smart phones for accountable care and evidence-based decision making in the management of gestational diabetes. Proceedings - Pacific Asia Conference on Information Systems, PACIS 2014; 2014.

59. Kaplan R. "SUGAMAMA" - GESTATIONAL DIABETES MOBILE 'APP' INNOVATION IN INTEGRATED CARE PROOF OF CONCEPT. International Journal of Integrated Care. 2014;14.

60. Grabosch S, Gavard JA, Mostello D. Text4baby improves glycemic control in pregnant women with diabetes. American Journal of Obstetrics and Gynecology. 2014;210(1):S88.

61. Shivanath M, Nayar R, Emmerson C, Loughney A, Purvis A, Fairs A, et al. Will 'simple telehealth' help in the management of women with gestational diabetes? BJOG: An International Journal of Obstetrics and Gynaecology. 2013;120:111.

62. Shea AK, Shah BR, Clark HD, Malcolm J, Walker M, Karovitch A, et al. The effectiveness of implementing a reminder system into routine clinical practice: does it increase postpartum screening in women with gestational diabetes? Chronic Diseases in Canada. 2011;31(2):58-64.

63. Perez-Ferre N, Galindo M, Fernandez MD, Velasco V, Runkle I, de la Cruz MJ, et al. The Outcomes of Gestational Diabetes Mellitus after a Telecare Approach Are Not Inferior to Traditional Outpatient Clinic Visits. International Journal of Endocrinology. 2010.

64. Wickramasinghe N, Singh M, Troshani I, Hill SR, Hague W, Goldberg S, editors. A pervasive technology solution for diabetes using gestational diabetes as a model. 16th Americas Conference on Information Systems 2010, AMCIS 2010; 2010.

65. Dalfra MG, Nicolucci A, Lapolla A. The effect of telemedicine on outcome and quality of life in pregnant women with diabetes. J Telemed Telecare. 2009;15(5):238-42.

66. Pais S, Parry D, Rowan J, editors. A framework of evaluation of mobile wellness apps for use in a clinical setting. TENSYMP 2017 - IEEE International Symposium on Technologies for Smart Cities; 2017.

67. Kay M, Santos J, Takane M. mHealth: New horizons for health through mobile technologies. World Health Organization. 2011;64(7):66-71.

68. Zvornicanin E, Zvornicanin J, Hadziefendic B. The use of smart phones in ophthalmology. Acta Informatica Medica. 2014;22(3):206.

69. Milanese S, Gordon S, Buettner P, Flavell C, Ruston S, Coe D, et al. Reliability and concurrent validity of knee angle measurement: smart phone app versus universal goniometer used by experienced and novice clinicians. Manual therapy. 2014;19(6):569-74.

70. Capozzi D, Lanzola G. Utilizing information technologies for lifelong monitoring in diabetes patients. SAGE Publications; 2011. 
71. Derbyshire E, Dancey D. Smartphone medical applications for women's health: What is the evidencebase and feedback? International journal of telemedicine and applications. 2013;2013:9.

72. Gislason B, McKnight C, Potvin B, Stuart S, Zepeda J, Weber J, et al., editors. Introducing glucofit: An assistive technology for monitoring and managing diabetes. Proceedings - 2012 7th International Conference on Broadband, Wireless Computing, Communication and Applications, BWCCA 2012; 2012.

73. Heatley E, Middleton P, Hague W, Crowther C. The DIAMIND study: Postpartum SMS reminders to women who have had gestational diabetes mellitus to test for type 2 diabetes: A randomised controlled trial - study protocol. BMC Pregnancy and Childbirth. 2013;13.

74. Kasmeridis NC, Vassilakopoulos MG, editors. A diet-guide mobile application for diabetes mellitus management. ACM International Conference Proceeding Series; 2015.

75. Kim YJ, Rhee SY, Byun JK, Park SY, Hong SM, Chin SO, et al. A smartphone application significantly improved diabetes self-care activities with high user satisfaction. Diabetes \& metabolism journal. 2015;39(3):207-17.

76. Mackillop L, Loerup L, Bartlett K, Farmer A, Gibson OJ, Hirst JE, et al. Development of a real-time smartphone solution for the management of women with or at high risk of gestational diabetes. Journal of diabetes science and technology. 2014;8(6):1105-14.

77. O'Sullivan EJ, Kennelly MA, Rokicki S, Ainscough K, McAuliffe FM. Cost-effectiveness of a mobile health-supported lifestyle intervention for preventing gestational diabetes mellitus. American Journal of Obstetrics and Gynecology. 2018;218(1):S380-S1.

78. Pal K, Eastwood SV, Michie S, Farmer A, Barnard ML, Peacock R, et al. Computer-based interventions to improve self-management in adults with type 2 diabetes: a systematic review and meta-analysis. Diabetes care. 2014;37(6):1759-66.

79. Wickramasinghe N, Gururajan R. Innovation Practice Using Pervasive Mobile Technology Solutions to Improve Population Health Management: A Pilot Study of Gestational Diabetes Patient Care in Australia. Journal for Healthcare Quality. 2016;38(2):93-105.

80. Wu Y, Yao X, Vespasiani G, Nicolucci A, Dong Y, Kwong J, et al. Mobile app-based interventions to support diabetes self-management: a systematic review of randomized controlled trials to identify functions associated with glycemic efficacy. JMIR mHealth and uHealth. 2017;5(3).

81. McMillan B, Abdelgalil R, Madhuvrata P, Easton K, Mitchell C. Reducing the risk of type 2 diabetes mellitus in primary care after gestational diabetes: a role for mobile technology to improve current care. British Journal of General Practice. 2016;66(653):631-2.

82. Rasekaba TM, Furler J, Young D, Liew D, Gray K, Blackberry I, et al. Using Technology to Support Care in Gestational Diabetes Mellitus: Quantitative Outcomes of an Exploratory Randomised Control Trial of Adjunct Telemedicine for Gestational Diabetes Mellitus (TeleGDM). Diabetes research and clinical practice. 2018.

83. Given JE, Bunting BP, O'Kane MJ, Dunne F, Coates VE. Tele-Mum: A Feasibility Study for a Randomized Controlled Trial Exploring the Potential for Telemedicine in the Diabetes Care of Those with Gestational Diabetes. Diabetes Technol Ther. 2015;17(12):880-8.

84. Huberty J, Rowedder L, Hekler E, Adams M, Hanigan E, McClain D, et al. Development and design of an intervention to improve physical activity in pregnant women using Text4baby. Translational Behavioral Medicine. 2016;6(2):285-94.

85. Poston L, Bell R, Croker H, Flynn AC, Godfrey KM, Goff L, et al. Effect of a behavioural intervention in obese pregnant women (the UPBEAT study): a multicentre, randomised controlled trial. The lancet Diabetes \& endocrinology. 2015;3(10):767-77. 
86. Dodd JM, Turnbull D, McPhee AJ, Deussen AR, Grivell RM, Yelland LN, et al. Antenatal lifestyle advice for women who are overweight or obese: LIMIT randomised trial. Bmj. 2014;348:g1285.

87. Jareethum R, Titapant V, Tienthai C, Viboonchart S, Chuenwattana P, Chatchainoppakhun J. Satisfaction of healthy pregnant women receiving short message service via mobile phone for prenatal support: A randomized controlled trial. Journal of the Medical Association of Thailand. 2008;91(4):458-63.

88. Hennemann S, Beutel ME, Zwerenz R. Ready for eHealth? Health professionals' acceptance and adoption of ehealth interventions in inpatient routine care. Journal of health communication. 2017;22(3):274-84.

Table1. PubMed search query

\begin{tabular}{ll}
\hline Step in search Strategy & Search term \\
\hline 1 & mobile health OR mobile OR mhealth OR m-health OR mobile technology OR smartphone OR $n$ \\
2 & (Diabetes, Pregnancy-Induced) OR (Diabetes, Pregnancy Induced) OR (Pregnancy-Induced Diab \\
3 & $2000 / 01 / 01: 2018 / 11 / 15[$ dp] \\
4 & 1 AND 2 AND 3 \\
\hline
\end{tabular}

Table2. Reviewed papers' characteristics and M-Health interventions and results from studies

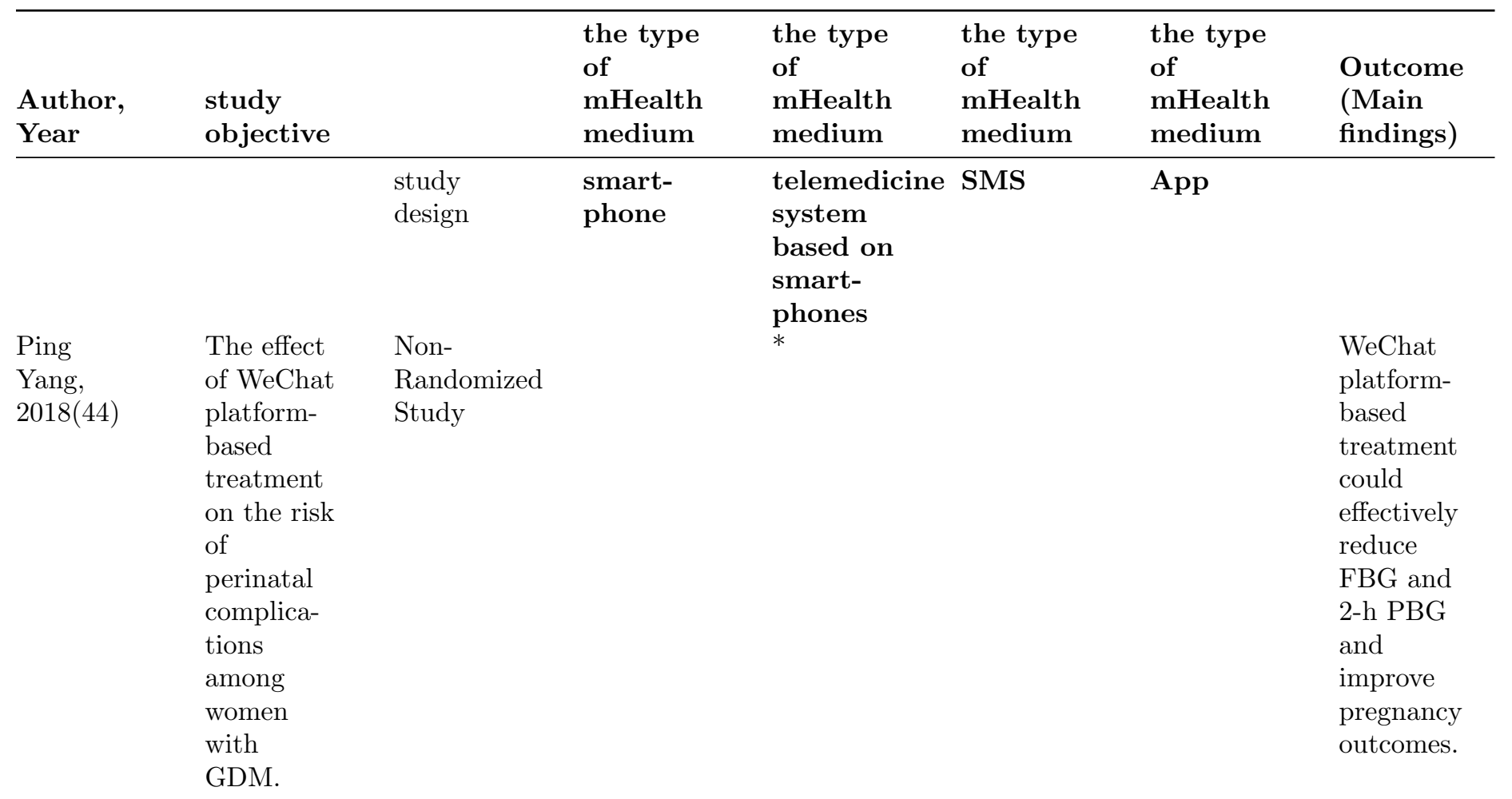




\begin{tabular}{|c|c|c|c|c|c|c|c|}
\hline $\begin{array}{l}\text { Author, } \\
\text { Year }\end{array}$ & $\begin{array}{l}\text { study } \\
\text { objective }\end{array}$ & & $\begin{array}{l}\text { the type } \\
\text { of } \\
\text { mHealth } \\
\text { medium }\end{array}$ & $\begin{array}{l}\text { the type } \\
\text { of } \\
\text { mHealth } \\
\text { medium }\end{array}$ & $\begin{array}{l}\text { the type } \\
\text { of } \\
\text { mHealth } \\
\text { medium }\end{array}$ & $\begin{array}{l}\text { the type } \\
\text { of } \\
\text { mHealth } \\
\text { medium }\end{array}$ & $\begin{array}{l}\text { Outcome } \\
\text { (Main } \\
\text { findings) }\end{array}$ \\
\hline $\begin{array}{l}\text { Skar, } \\
2018(45)\end{array}$ & $\begin{array}{l}\text { The effect } \\
\text { of smart- } \\
\text { phone app } \\
\text { (the Preg- } \\
\text { nant+ } \\
\text { app) on } \\
\text { controlling } \\
\text { blood } \\
\text { glucose } \\
\text { levels and } \\
\text { receiving } \\
\text { health and } \\
\text { nutrition } \\
\text { informa- } \\
\text { tion in } \\
\text { women } \\
\text { with } \\
\text { GDM. }\end{array}$ & RCT & & & & $*$ & $\begin{array}{l}\text { Smartphone } \\
\text { app could } \\
\text { assist } \\
\text { women } \\
\text { with } \\
\text { GDM to } \\
\text { control } \\
\text { their } \\
\text { blood } \\
\text { glucose } \\
\text { and } \\
\text { increased } \\
\text { their } \\
\text { confidence } \\
\text { in self- } \\
\text { management. }\end{array}$ \\
\hline $\begin{array}{l}\text { Miremberg, } \\
2018(46)\end{array}$ & $\begin{array}{l}\text { The } \\
\text { impact of } \\
\text { a } \\
\text { smartphone- } \\
\text { based } \\
\text { daily } \\
\text { feedback } \\
\text { and } \\
\text { communi- } \\
\text { cation } \\
\text { platform } \\
\text { on GDM } \\
\text { patients' } \\
\text { compli- } \\
\text { ance, } \\
\text { glycemic } \\
\text { control, } \\
\text { pregnancy } \\
\text { outcome, } \\
\text { and } \\
\text { satisfaction }\end{array}$ & $\mathrm{RCT}$ & $*$ & & & & $\begin{array}{l}\text { Smartphone- } \\
\text { based } \\
\text { technology } \\
\text { could } \\
\text { enhance } \\
\text { the } \\
\text { adherence } \\
\text { to self- } \\
\text { performed } \\
\text { BG moni- } \\
\text { toring and } \\
\text { glycemic } \\
\text { control } \\
\text { parame- } \\
\text { ters such } \\
\text { as mean } \\
\text { blood } \\
\text { glucose, } \\
\text { off-target } \\
\text { measure- } \\
\text { ments, } \\
\text { and the } \\
\text { need for } \\
\text { insulin } \\
\text { treatment. }\end{array}$ \\
\hline
\end{tabular}




\begin{tabular}{|c|c|c|c|c|c|c|c|}
\hline $\begin{array}{l}\text { Author, } \\
\text { Year }\end{array}$ & $\begin{array}{l}\text { study } \\
\text { objective }\end{array}$ & & $\begin{array}{l}\text { the type } \\
\text { of } \\
\text { mHealth } \\
\text { medium }\end{array}$ & $\begin{array}{l}\text { the type } \\
\text { of } \\
\text { mHealth } \\
\text { medium }\end{array}$ & $\begin{array}{l}\text { the type } \\
\text { of } \\
\text { mHealth } \\
\text { medium }\end{array}$ & $\begin{array}{l}\text { the type } \\
\text { of } \\
\text { mHealth } \\
\text { medium }\end{array}$ & $\begin{array}{l}\text { Outcome } \\
\text { (Main } \\
\text { findings) }\end{array}$ \\
\hline $\begin{array}{l}\text { Mackillop, } \\
2018(47)\end{array}$ & $\begin{array}{l}\text { The use of } \\
\text { a mobile } \\
\text { phone- } \\
\text { based } \\
\text { real-time } \\
\text { blood } \\
\text { glucose } \\
\text { manage- } \\
\text { ment } \\
\text { system to } \\
\text { control } \\
\text { GDM } \\
\text { patients' } \\
\text { blood } \\
\text { glucose. }\end{array}$ & $\mathrm{RCT}$ & $*$ & & & & $\begin{array}{l}\text { Remote } \\
\text { monitor- } \\
\text { ing of } \\
\text { blood } \\
\text { glucose is } \\
\text { safe in } \\
\text { women } \\
\text { with } \\
\text { GDM. }\end{array}$ \\
\hline $\begin{array}{l}\text { Rigla, } \\
2018(48)\end{array}$ & $\begin{array}{l}\text { The } \\
\text { efficacy of } \\
\text { smart } \\
\text { mobile } \\
\text { telemedicine } \\
\text { in moni- } \\
\text { toring } \\
\text { blood } \\
\text { glucose of } \\
\text { GDM } \\
\text { patients. }\end{array}$ & $\begin{array}{l}\text { Pilot } \\
\text { Study }\end{array}$ & & $*$ & & & $\begin{array}{l}\text { This study } \\
\text { This } \\
\text { decision } \\
\text { support } \\
\text { system } \\
\text { was a } \\
\text { feasible } \\
\text { and well- } \\
\text { accepted } \\
\text { system for } \\
\text { monitor- } \\
\text { ing } \\
\text { GDM. }\end{array}$ \\
\hline $\begin{array}{l}\text { Kennelly, } \\
2018(42)\end{array}$ & $\begin{array}{l}\text { The } \\
\text { impact of } \\
\text { a healthy } \\
\text { lifestyle } \\
\text { package } \\
\text { using } \\
\text { smart- } \\
\text { phone } \\
\text { applica- } \\
\text { tion } \\
\text { technology } \\
\text { on the } \\
\text { prevalence } \\
\text { of GDM in } \\
\text { overweight } \\
\text { and obese } \\
\text { women. }\end{array}$ & $\mathrm{RCT}$ & & & & $*$ & $\begin{array}{l}\text { This inter- } \\
\text { vention } \\
\text { could not } \\
\text { decrease } \\
\text { the } \\
\text { prevalence } \\
\text { of GDM. }\end{array}$ \\
\hline
\end{tabular}




\begin{tabular}{|c|c|c|c|c|c|c|c|}
\hline $\begin{array}{l}\text { Author, } \\
\text { Year }\end{array}$ & $\begin{array}{l}\text { study } \\
\text { objective }\end{array}$ & & $\begin{array}{l}\text { the type } \\
\text { of } \\
\text { mHealth } \\
\text { medium }\end{array}$ & $\begin{array}{l}\text { the type } \\
\text { of } \\
\text { mHealth } \\
\text { medium }\end{array}$ & $\begin{array}{l}\text { the type } \\
\text { of } \\
\text { mHealth } \\
\text { medium }\end{array}$ & $\begin{array}{l}\text { the type } \\
\text { of } \\
\text { mHealth } \\
\text { medium }\end{array}$ & $\begin{array}{l}\text { Outcome } \\
\text { (Main } \\
\text { findings) }\end{array}$ \\
\hline $\begin{array}{l}\text { Johnson, } \\
2018(49)\end{array}$ & $\begin{array}{l}\text { The effect of } \\
\text { short } \\
\text { messaging } \\
\text { reminders } \\
\text { on diabetes } \\
\text { self- } \\
\text { management } \\
\text { in women } \\
\text { with GDM }\end{array}$ & $\mathrm{RCT}$ & & & $*$ & & $\begin{array}{l}\text { The use of } \\
\text { daily text } \\
\text { messages } \\
\text { was } \\
\text { acceptable } \\
\text { for patients } \\
\text { with GDM } \\
\text { seems. In } \\
\text { addition, an } \\
\text { overall } \\
\text { satisfaction } \\
\text { with the } \\
\text { messages } \\
\text { and } \\
\text { willingness } \\
\text { to use the } \\
\text { messages in } \\
\text { future } \\
\text { pregnancies } \\
\text { and to } \\
\text { recommend } \\
\text { the messages } \\
\text { to friends } \\
\text { with GDM } \\
\text { were } \\
\text { obtained. }\end{array}$ \\
\hline $\begin{array}{l}\text { Garnweidner- } \\
\text { Holme, } \\
2018(9)\end{array}$ & $\begin{array}{l}\text { The } \\
\text { usefulness } \\
\text { of culture- } \\
\text { sensitive } \\
\text { pregnant } \\
\text { applica- } \\
\text { tion for } \\
\text { pregnant } \\
\text { women } \\
\text { with } \\
\text { GDM } \\
\text { according } \\
\text { to health } \\
\text { care pro- } \\
\text { fessionals' } \\
\text { perspectives }\end{array}$ & $\begin{array}{l}\text { Qualitative } \\
\text { Study }\end{array}$ & & & & $*$ & $\begin{array}{l}\text { M-Health } \\
\text { interven- } \\
\text { tion was a } \\
\text { useful tool } \\
\text { to improve } \\
\text { the care } \\
\text { provided } \\
\text { by health } \\
\text { care pro- } \\
\text { fessionals } \\
\text { to women } \\
\text { with } \\
\text { GDM. }\end{array}$ \\
\hline
\end{tabular}




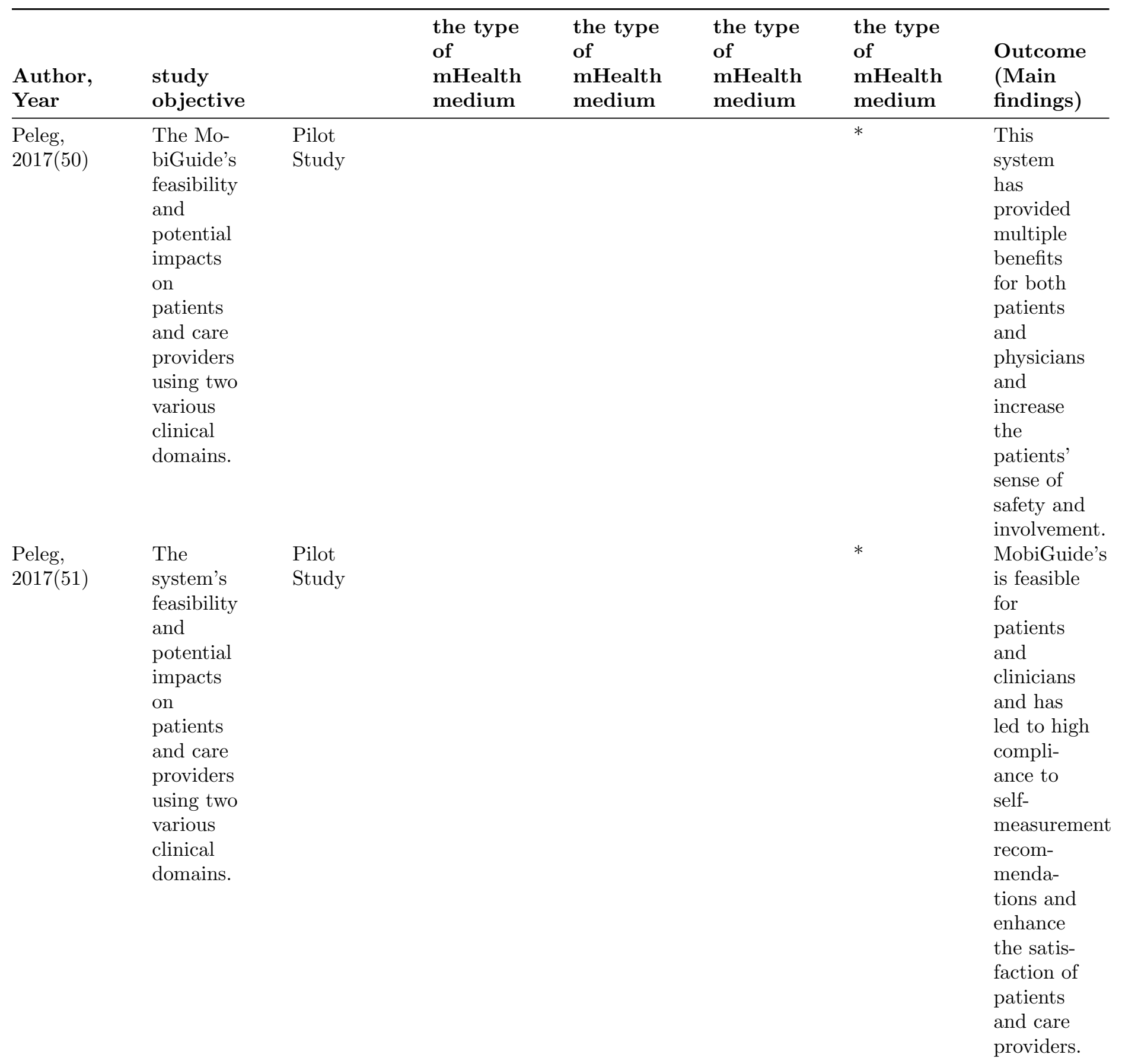




\begin{tabular}{|c|c|c|c|c|c|c|c|}
\hline $\begin{array}{l}\text { Author, } \\
\text { Year }\end{array}$ & $\begin{array}{l}\text { study } \\
\text { objective }\end{array}$ & & $\begin{array}{l}\text { the type } \\
\text { of } \\
\text { mHealth } \\
\text { medium }\end{array}$ & $\begin{array}{l}\text { the type } \\
\text { of } \\
\text { mHealth } \\
\text { medium }\end{array}$ & $\begin{array}{l}\text { the type } \\
\text { of } \\
\text { mHealth } \\
\text { medium }\end{array}$ & $\begin{array}{l}\text { the type } \\
\text { of } \\
\text { mHealth } \\
\text { medium }\end{array}$ & $\begin{array}{l}\text { Outcome } \\
\text { (Main } \\
\text { findings) }\end{array}$ \\
\hline $\begin{array}{l}\text { McLean, } \\
\text { A. } \\
2017(41)\end{array}$ & $\begin{array}{l}\text { The } \\
\text { efficacy of } \\
\text { real-time } \\
\text { smart- } \\
\text { phone } \\
\text { data in } \\
\text { improving } \\
\text { clinical } \\
\text { manage- } \\
\text { ment and } \\
\text { outcomes } \\
\text { of women } \\
\text { at GDM } \\
\text { risk }\end{array}$ & $\begin{array}{l}\text { Pilot } \\
\text { Study }\end{array}$ & $*$ & & & & $\begin{array}{l}\text { Real-time } \\
\text { individual } \\
\text { health and } \\
\text { sensor } \\
\text { data can } \\
\text { be readily } \\
\text { collected } \\
\text { and } \\
\text { analyzed } \\
\text { efficiently } \\
\text { while con- } \\
\text { fidentiality } \\
\text { is main- } \\
\text { tained; } \\
\text { however, } \\
\text { improved } \\
\text { prediction } \\
\text { of GDM is } \\
\text { not } \\
\text { obtained. }\end{array}$ \\
\hline
\end{tabular}




\begin{tabular}{|c|c|c|c|c|c|c|c|}
\hline $\begin{array}{l}\text { Author, } \\
\text { Year }\end{array}$ & $\begin{array}{l}\text { study } \\
\text { objective }\end{array}$ & & $\begin{array}{l}\text { the type } \\
\text { of } \\
\text { mHealth } \\
\text { medium }\end{array}$ & $\begin{array}{l}\text { the type } \\
\text { of } \\
\text { mHealth } \\
\text { medium }\end{array}$ & $\begin{array}{l}\text { the type } \\
\text { of } \\
\text { mHealth } \\
\text { medium }\end{array}$ & $\begin{array}{l}\text { the type } \\
\text { of } \\
\text { mHealth } \\
\text { medium }\end{array}$ & $\begin{array}{l}\text { Outcome } \\
\text { (Main } \\
\text { findings) }\end{array}$ \\
\hline $\begin{array}{l}\text { Nicholson, } \\
2016(52)\end{array}$ & $\begin{array}{l}\text { The } \\
\text { efficacy of } \\
\text { a } \\
\text { web-based } \\
\text { pregnancy } \\
\text { and post- } \\
\text { partum } \\
\text { behavioral } \\
\text { interven- } \\
\text { tion in } \\
\text { contribut- } \\
\text { ing women } \\
\text { with } \\
\text { GDM to } \\
\text { control } \\
\text { weight } \\
\text { and } \\
\text { glucose } \\
\text { during } \\
\text { pregnancy } \\
\text { and } \\
\text { postpartum. }\end{array}$ & $\mathrm{RCT}$ & & & $*$ & & $\begin{array}{l}\text { The } \\
\text { web-based } \\
\text { behavioral } \\
\text { interven- } \\
\text { tion } \\
\text { coupled } \\
\text { with text } \\
\text { messages } \\
\text { and emails } \\
\text { and } \\
\text { tailored to } \\
\text { the needs } \\
\text { of women } \\
\text { with } \\
\text { GDM is } \\
\text { feasible } \\
\text { and well } \\
\text { received } \\
\text { by partici- } \\
\text { pants. } \\
\text { This study } \\
\text { also shows } \\
\text { that } \\
\text { GooD- } \\
\text { Moms can } \\
\text { change the } \\
\text { current } \\
\text { paradigm } \\
\text { of } \\
\text { pregnancy } \\
\text { care for } \\
\text { women } \\
\text { with } \\
\text { GDM. }\end{array}$ \\
\hline
\end{tabular}




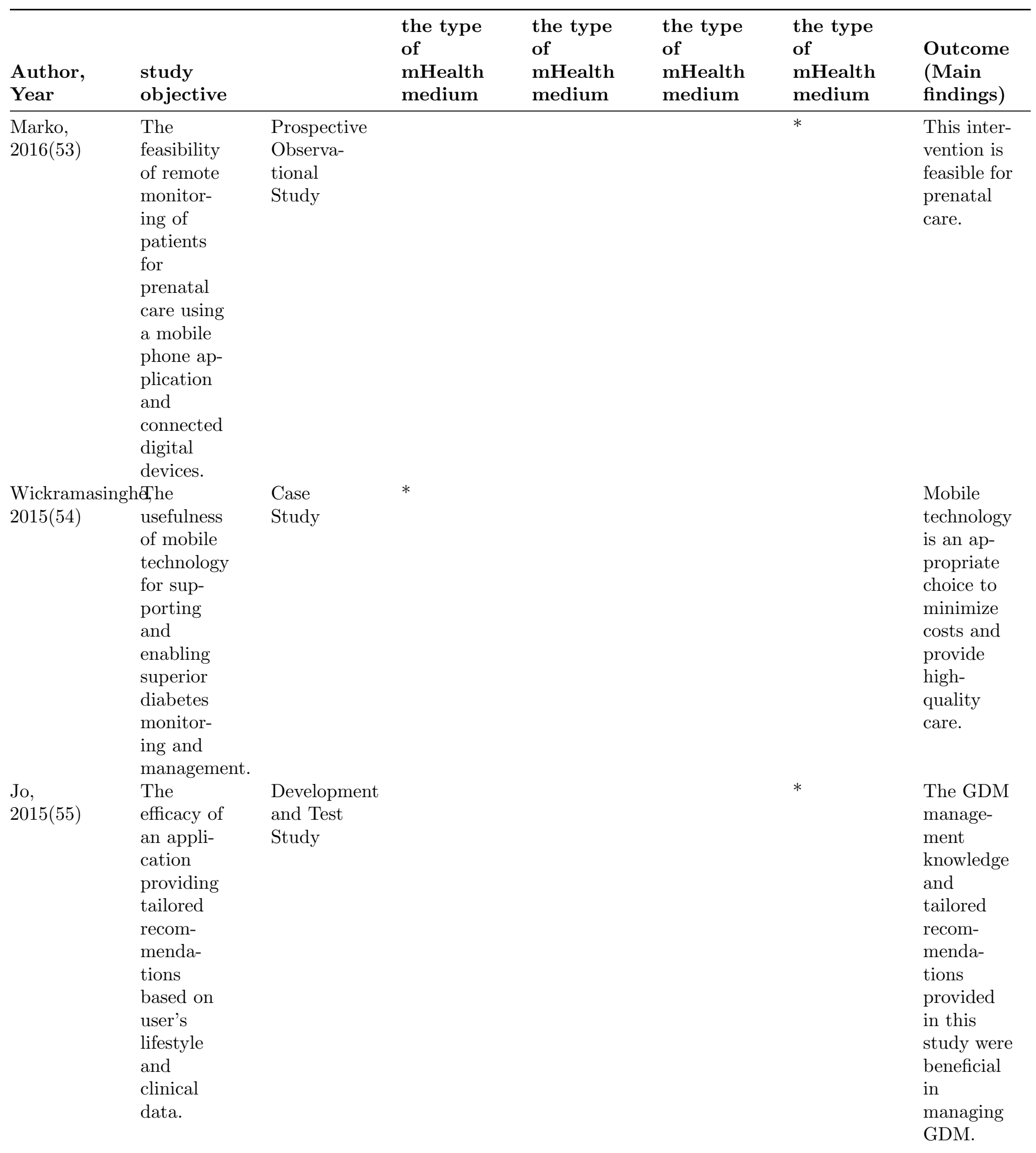




\begin{tabular}{|c|c|c|c|c|c|c|c|}
\hline $\begin{array}{l}\text { Author, } \\
\text { Year }\end{array}$ & $\begin{array}{l}\text { study } \\
\text { objective }\end{array}$ & & $\begin{array}{l}\text { the type } \\
\text { of } \\
\text { mHealth } \\
\text { medium }\end{array}$ & $\begin{array}{l}\text { the type } \\
\text { of } \\
\text { mHealth } \\
\text { medium }\end{array}$ & $\begin{array}{l}\text { the type } \\
\text { of } \\
\text { mHealth } \\
\text { medium }\end{array}$ & $\begin{array}{l}\text { the type } \\
\text { of } \\
\text { mHealth } \\
\text { medium }\end{array}$ & $\begin{array}{l}\text { Outcome } \\
\text { (Main } \\
\text { findings) }\end{array}$ \\
\hline $\begin{array}{l}\text { Van } \\
\text { Ryswyk, } \\
2015(40)\end{array}$ & $\begin{array}{l}\text { The effect } \\
\text { of SMS } \\
\text { reminder } \\
\text { system on } \\
\text { postpar- } \\
\text { tum oral } \\
\text { glucose } \\
\text { tolerance } \\
\text { test, } \\
\text { fasting } \\
\text { plasma } \\
\text { glucose, } \\
\text { and } \\
\text { HbA1c } \\
\text { completion. }\end{array}$ & $\mathrm{RCT}$ & & & $*$ & & $\begin{array}{l}\text { The SMS } \\
\text { reminder } \\
\text { system } \\
\text { cannot } \\
\text { enhance } \\
\text { postpar- } \\
\text { tum } \\
\text { OGTT, } \\
\text { fasting } \\
\text { plasma } \\
\text { glucose, or } \\
\text { HbA1c } \\
\text { completion. }\end{array}$ \\
\hline $\begin{array}{l}\text { Mohd } \\
\text { Suan, } \\
2015(56)\end{array}$ & $\begin{array}{l}\text { The } \\
\text { prevalence } \\
\text { and char- } \\
\text { acteristics } \\
\text { of patients } \\
\text { who did } \\
\text { and did } \\
\text { not return } \\
\text { for the } \\
\text { OGTT } \\
\text { and the } \\
\text { reasons } \\
\text { provided } \\
\text { by women } \\
\text { for failure } \\
\text { to return } \\
\text { for OGTT } \\
\text { test. }\end{array}$ & $\begin{array}{l}\text { Cross- } \\
\text { sectional } \\
\text { Study }\end{array}$ & & & $*$ & & $\begin{array}{l}\text { The } \\
\text { prevalence } \\
\text { of women } \\
\text { who } \\
\text { returned } \\
\text { for the } \\
\text { postpar- } \\
\text { tum } \\
\text { diabetic } \\
\text { screening } \\
\text { test was } \\
\text { high. This } \\
\text { study also } \\
\text { provides } \\
\text { valuable } \\
\text { insights } \\
\text { into } \\
\text { several } \\
\text { obstacles } \\
\text { that } \\
\text { render the } \\
\text { return for } \\
\text { the } \\
\text { glucose } \\
\text { tolerance } \\
\text { test. }\end{array}$ \\
\hline
\end{tabular}




\begin{tabular}{|c|c|c|c|c|c|c|c|}
\hline $\begin{array}{l}\text { Author, } \\
\text { Year }\end{array}$ & $\begin{array}{l}\text { study } \\
\text { objective }\end{array}$ & & $\begin{array}{l}\text { the type } \\
\text { of } \\
\text { mHealth } \\
\text { medium }\end{array}$ & $\begin{array}{l}\text { the type } \\
\text { of } \\
\text { mHealth } \\
\text { medium }\end{array}$ & $\begin{array}{l}\text { the type } \\
\text { of } \\
\text { mHealth } \\
\text { medium }\end{array}$ & $\begin{array}{l}\text { the type } \\
\text { of } \\
\text { mHealth } \\
\text { medium }\end{array}$ & $\begin{array}{l}\text { Outcome } \\
\text { (Main } \\
\text { findings) }\end{array}$ \\
\hline $\begin{array}{l}\text { Hirst, } \\
2015(57)\end{array}$ & $\begin{array}{l}\text { Women's } \\
\text { satisfac- } \\
\text { tion with } \\
\text { using the } \\
\text { GDM- } \\
\text { health } \\
\text { system } \\
\text { and their } \\
\text { attitudes } \\
\text { toward } \\
\text { their } \\
\text { diabetes } \\
\text { care. }\end{array}$ & $\begin{array}{l}\text { Pilot } \\
\text { Study }\end{array}$ & & & & $*$ & $\begin{array}{l}\text { GDm- } \\
\text { health was } \\
\text { acceptable } \\
\text { and } \\
\text { convenient } \\
\text { for a large } \\
\text { proportion } \\
\text { of women. }\end{array}$ \\
\hline $\begin{array}{l}\text { Teoh, } \\
2014(58)\end{array}$ & $\begin{array}{l}\text { The } \\
\text { efficacy of } \\
\text { smart- } \\
\text { phones on } \\
\text { GDM } \\
\text { Monitor- } \\
\text { ing among } \\
\text { Australian } \\
\text { women. }\end{array}$ & $\mathrm{RCT}$ & $*$ & & & & $\begin{array}{l}\text { The use of } \\
\text { smart- } \\
\text { phones to } \\
\text { support } \\
\text { GDM self- } \\
\text { management } \\
\text { facilitates } \\
\text { superior } \\
\text { monitor- } \\
\text { ing and } \\
\text { manage- } \\
\text { ment of } \\
\text { GDM and } \\
\text { supports } \\
\text { the ac- } \\
\text { countable } \\
\text { care } \\
\text { paradigm. }\end{array}$ \\
\hline $\begin{array}{l}\text { Kaplan, } \\
2014(59)\end{array}$ & $\begin{array}{l}\text { Efficacy of } \\
\text { a mobile } \\
\text { applica- } \\
\text { tion and } \\
\text { web-based } \\
\text { system in } \\
\text { promoting } \\
\text { self- } \\
\text { management } \\
\text { of women } \\
\text { with } \\
\text { GDM. }\end{array}$ & $\begin{array}{l}\text { Pilot } \\
\text { Study }\end{array}$ & & & & $*$ & $\begin{array}{l}\text { This } \\
\text { mobile ap- } \\
\text { plication } \\
\text { and } \\
\text { web-based } \\
\text { system } \\
\text { can } \\
\text { promote } \\
\text { self- } \\
\text { management } \\
\text { of women } \\
\text { with } \\
\text { GDM }\end{array}$ \\
\hline
\end{tabular}




\begin{tabular}{|c|c|c|c|c|c|c|c|}
\hline $\begin{array}{l}\text { Author, } \\
\text { Year }\end{array}$ & $\begin{array}{l}\text { study } \\
\text { objective }\end{array}$ & & $\begin{array}{l}\text { the type } \\
\text { of } \\
\text { mHealth } \\
\text { medium }\end{array}$ & $\begin{array}{l}\text { the type } \\
\text { of } \\
\text { mHealth } \\
\text { medium }\end{array}$ & $\begin{array}{l}\text { the type } \\
\text { of } \\
\text { mHealth } \\
\text { medium }\end{array}$ & $\begin{array}{l}\text { the type } \\
\text { of } \\
\text { mHealth } \\
\text { medium }\end{array}$ & $\begin{array}{l}\text { Outcome } \\
\text { (Main } \\
\text { findings) }\end{array}$ \\
\hline $\begin{array}{l}\text { Grabosch, } \\
2014(60)\end{array}$ & $\begin{array}{l}\text { The } \\
\text { feasibility } \\
\text { of a text } \\
\text { message } \\
\text { reminder } \\
\text { system for } \\
\text { pregnant } \\
\text { women } \\
\text { with } \\
\text { diabetes } \\
\text { from a } \\
\text { low- } \\
\text { income } \\
\text { popula- } \\
\text { tion, and } \\
\text { its impact } \\
\text { on } \\
\text { adherence } \\
\text { to a } \\
\text { diabetes } \\
\text { care } \\
\text { regimen } \\
\text { and subse- } \\
\text { quent } \\
\text { glycemic } \\
\text { control }\end{array}$ & $\mathrm{RCT}$ & & & $*$ & & $\begin{array}{l}\text { The text } \\
\text { message } \\
\text { reminder } \\
\text { system is } \\
\text { feasible for } \\
\text { pregnant } \\
\text { women } \\
\text { with } \\
\text { diabetes } \\
\text { from a } \\
\text { low- } \\
\text { income } \\
\text { population } \\
\text { and } \\
\text { Text4baby } \\
\text { can be } \\
\text { used as an } \\
\text { educa- } \\
\text { tional tool } \\
\text { to improve } \\
\text { outcomes } \\
\text { in women } \\
\text { with } \\
\text { diabetes. }\end{array}$ \\
\hline
\end{tabular}




\begin{tabular}{|c|c|c|c|c|c|c|c|}
\hline $\begin{array}{l}\text { Author, } \\
\text { Year }\end{array}$ & $\begin{array}{l}\text { study } \\
\text { objective }\end{array}$ & & $\begin{array}{l}\text { the type } \\
\text { of } \\
\text { mHealth } \\
\text { medium }\end{array}$ & $\begin{array}{l}\text { the type } \\
\text { of } \\
\text { mHealth } \\
\text { medium }\end{array}$ & $\begin{array}{l}\text { the type } \\
\text { of } \\
\text { mHealth } \\
\text { medium }\end{array}$ & $\begin{array}{l}\text { the type } \\
\text { of } \\
\text { mHealth } \\
\text { medium }\end{array}$ & $\begin{array}{l}\text { Outcome } \\
\text { (Main } \\
\text { findings) }\end{array}$ \\
\hline $\begin{array}{l}\text { Shivanath, } \\
2014(61)\end{array}$ & $\begin{array}{l}\text { The } \\
\text { feasibility } \\
\text { of 'Simple } \\
\text { Tele- } \\
\text { health' for } \\
\text { women } \\
\text { with ges- } \\
\text { tational } \\
\text { diabetes, } \\
\text { patients' } \\
\text { treatment } \\
\text { satisfac- } \\
\text { tion with } \\
\text { this inter- } \\
\text { vention, } \\
\text { and the } \\
\text { economic } \\
\text { benefit of } \\
\text { this } \\
\text { system in } \\
\text { conjunc- } \\
\text { tion with } \\
\text { routine } \\
\text { antenatal } \\
\text { diabetes } \\
\text { care. }\end{array}$ & $\begin{array}{l}\text { Pilot } \\
\text { Study }\end{array}$ & & & $*$ & & $\begin{array}{l}\text { Short- } \\
\text { term use } \\
\text { of 'Simple } \\
\text { Tele- } \\
\text { health' is } \\
\text { associated } \\
\text { with high } \\
\text { treatment } \\
\text { satisfac- } \\
\text { tion levels } \\
\text { amongst } \\
\text { patients } \\
\text { with } \\
\text { GDM and } \\
\text { some } \\
\text { economic } \\
\text { benefits. }\end{array}$ \\
\hline $\begin{array}{l}\text { Homko, } \\
2012(43)\end{array}$ & $\begin{array}{l}\text { The } \\
\text { impact of } \\
\text { an } \\
\text { enhanced } \\
\text { telemedicine } \\
\text { system on } \\
\text { glucose } \\
\text { control } \\
\text { and } \\
\text { pregnancy } \\
\text { outcomes } \\
\text { in women } \\
\text { with } \\
\text { GDM. }\end{array}$ & $\mathrm{RCT}$ & & $*$ & & & $\begin{array}{l}\text { Enhanced } \\
\text { telemedicine } \\
\text { monitor- } \\
\text { ing system } \\
\text { increased } \\
\text { contact } \\
\text { between } \\
\text { women } \\
\text { with } \\
\text { GDM and } \\
\text { their } \\
\text { healthcare } \\
\text { providers } \\
\text { but did } \\
\text { not } \\
\text { influence } \\
\text { on } \\
\text { pregnancy } \\
\text { outcomes. }\end{array}$ \\
\hline
\end{tabular}




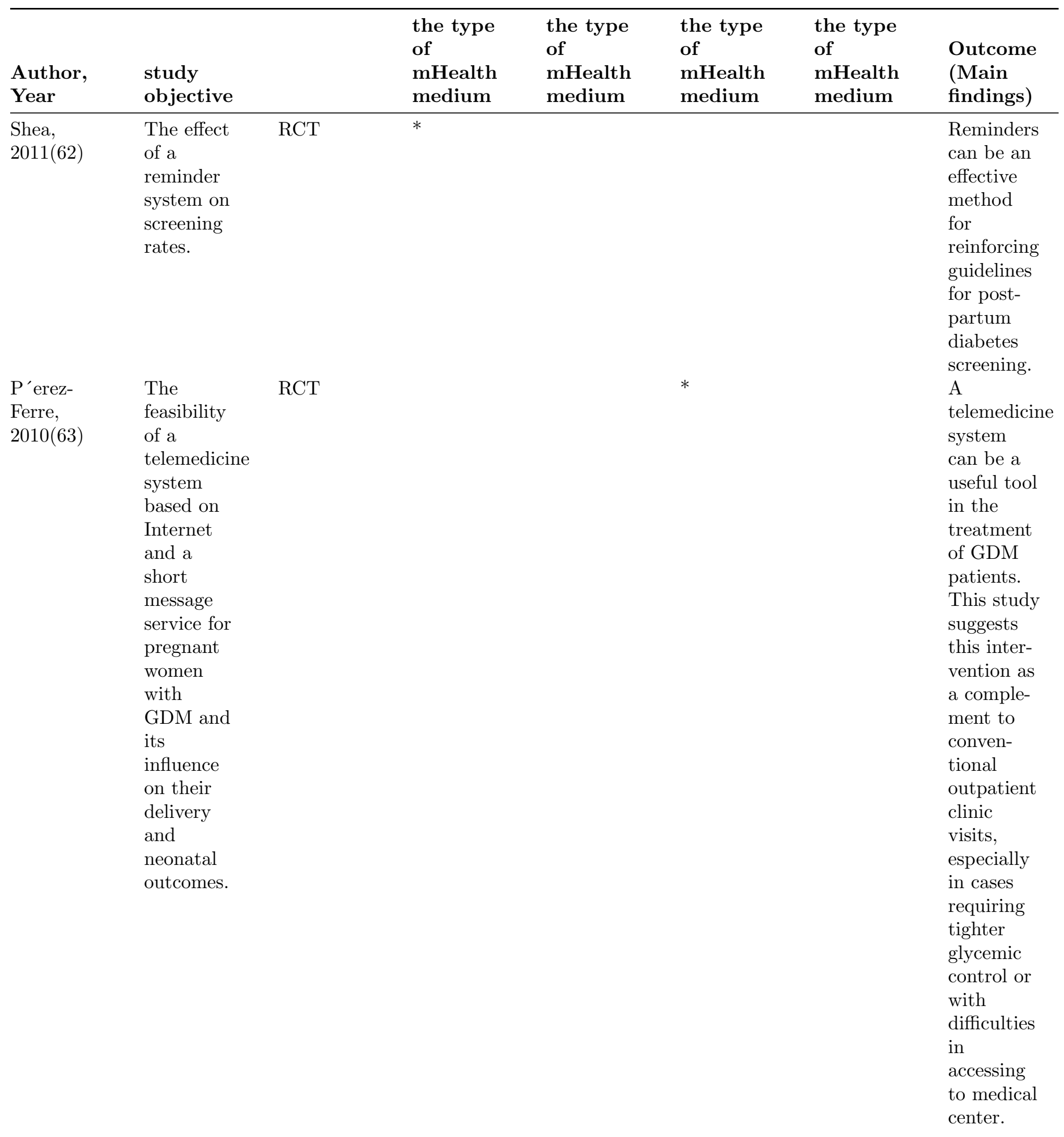




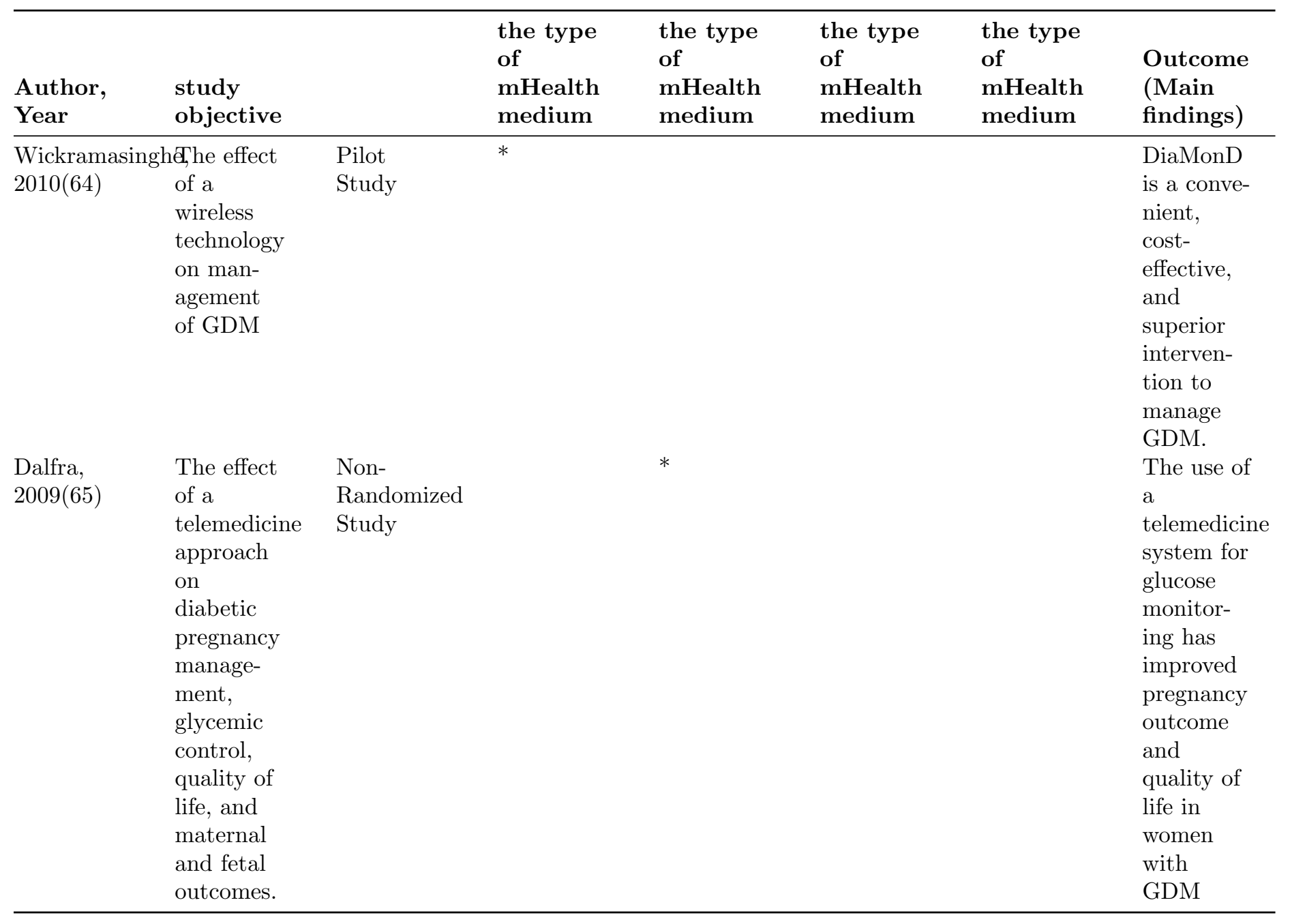

Figure 1. PRISMA Flow diagram of search strategy. 


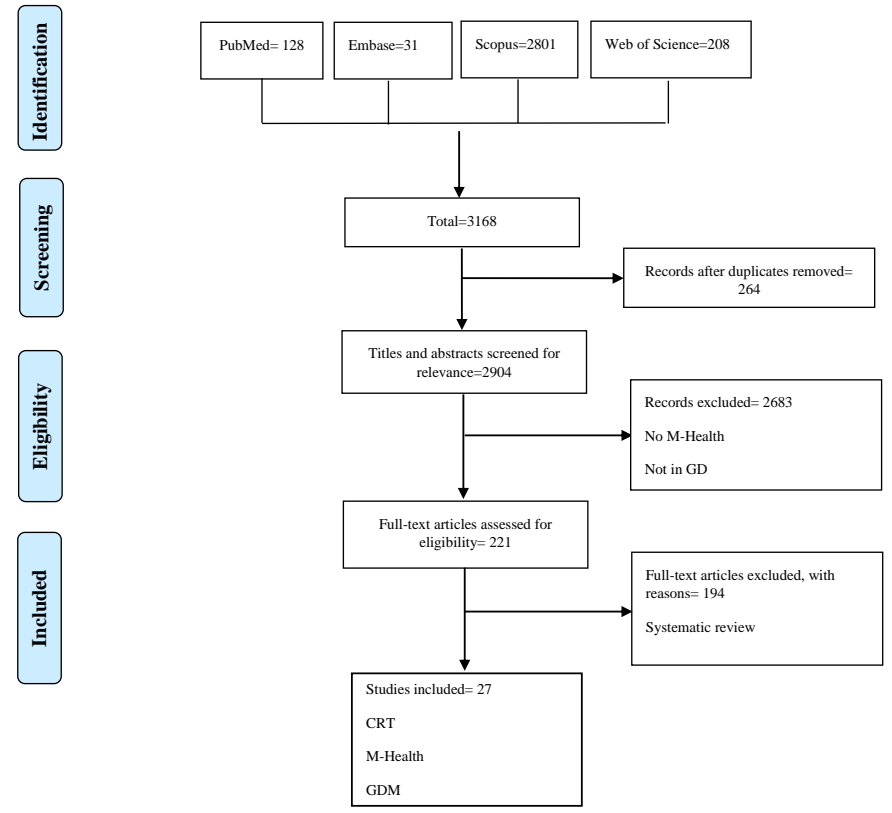

Figure 1. PRISMA Flow diagram of search strategy. 